\title{
MEDICAL QUALITY AND WELL-BEING PERCEPTION OF SENIOR TOURISTS
}

\author{
Pimtong Tavitiyaman', Wanlanai Saiprasert² \\ 1. School of Professional Education and Executive Development, The Hong Kong Polytechnic University, Hong Kong \\ 2. Management and Entrepreneurship Department, Faculty of Business Administration, Chiang Mai University, Thailand
} Correspondence: pimtong.t@cpce-polyu.edu.hk

\section{ABSTRACT}

\section{OBJECTIVES}

Advanced medical treatments and service quality for Hong Kong residents are well regarded. However, numerous senior residents continue to explore alternative medical treatments and wellbeing activities outside the region. The research objectives of this study are 1) to assess the perception of senior tourists of the medical quality attributes of medical tourism destinations and 2) to compare the different perceptions of tourists of medical service attributes, wellbeing and behavioural intention towards medical tourism destinations.

\section{DESIGN}

The questionnaire instrument was written in English and Chinese based on the literature review. The target population was senior residents with experience in seeking medical treatments and services abroad, specifically, outside Hong Kong. Convenience sampling was employed to recruit senior respondents to answer the questionnaire. Data collection was from July to October 2019 in residential areas and senior citizen neighbourhood centres in Hong Kong.

\section{RESULTS}

Results show that among the 74 respondents, only $42 \%$ have overseas medical experiences. The countries involved are Taiwan, South Korea, Japan, China, the United States, Malaysia and Thailand. The senior residents have a more positive perception of medical quality (e.g. appointment procedure, short waiting time and physician reliability) and wellbeing (e.g. response to needs and social wellbeing) in overseas medical destinations compared with Hong Kong. However, no mean difference is observed in behavioural intention between Hong Kong and overseas medical destinations from the perspective of the senior respondents.

\section{CONCLUSIONS}

Hong Kong senior residents may consider travelling overseas to seek medical treatments and wellbeing activities. Senior residents tend to travel to nearby countries for cosmetic/plastic surgery, eye surgery/Lasik and dental surgery. Moreover, senior residents perceive the communication skills of physicians and staff overseas in answering enquiries on medical procedures whilst receiving medical treatment as high quality compared with Hong Kong.

\section{KEYWORDS}

medical quality, wellbeing perception, behavioural intention, Hong Kong, medical destination, senior resident

\section{ACKNOWLEDGEMENT}

The work described in this paper was partially supported by a grant from the Research Grants Council of the Hong Kong Special Administrative Region, China (Project Reference No.: UGC/IDS24/18). 
The medical tourism industry integrates the medical and tourism sectors and is a specific form of tourism in which 'people travel to overseas countries to obtain medical, dental or surgical services whilst simultaneously being holiday makers, in the more conventional sense'. [1] Medical tourism presents outsourced medical services in other countries, where the costs of such offerings are lower than those in the tourists' home country. [2] According to the Transparency Market Research (2016), the benefits of medical tourism worldwide reached US $\$ 46$ billion in 2016. [3] Benefits of tourism are growing at a rate of more than $20 \%$ annually. [4]

A research gap exists in the academic examination of medical tourism. The concept of medical tourism has been investigated by numerous scholars, few studies have covered the development of medical tourism in Hong Kong, [5, 6] especially from the perspective of senior tourists. Senior groups as tourists are predicted to become a powerful consumer group in the future. [7] Senior tourists are not one large homogenous group, but small homogeneous groups based on reasons for travelling for pleasure. [8] People are living longer and seeking alternatives for curing sicknesses and enhancing wellbeing and quality of life. In addition, past travel experiences and media exposure can influence tourists' perception of medical tourism destinations. [9]

The purpose of this study includes the following: 1) to assess senior tourists' perception of the medical quality attributes of medical tourism destinations and 2) to compare tourists' different perceptions of medical service attributes, wellbeing and behavioural intention towards medical tourism destinations. This study can substantially contribute to medical tourism destinations in planning marketing campaigns to attract senior groups and promote sustainability.

\section{LITERATURE REVIEW}

\section{PERCEIVED MEDICAL SERVICE QUALITY FOR THE SILVER MARKET}

Service quality is often used to measure the delivery process (technical quality) and outcomes (functional quality). [10] Superior service quality can increase the level of patient-perceived value and satisfaction, which can

affect their behavioural intention. [10] Service quality in the medical sector includes aspects of technical and functional qualities that reflect tangible (e.g. appearance of physical facilities and medical equipment), expertise (e.g. staff performance in relation to tasks) and outcome (e.g. success of final treatment) quality measures. Chuang, Liu, Lu and Lee [11] explained the two main paths of medical tourism. The first path relates to the evolution of medical tourism and its association with problems, motivational factors, marketing strategies and economic analysis. The second path concerns organ transplantation, ethics, risks and regulatory-related issues. Medical tourism destinations have attempted to develop infrastructures and regulate proper healthcare policies to promote the optimistic prospects of the medical and healthcare industry. Although the advancement of medical treatments and services is well regarded in Hong Kong, limited resources in hospitals, clinics, physicians and staff exist. Certain residents prefer other countries as a travel alternative, including for receiving medical services.

The literature has explained the examination of medical tourism in numerous countries. For example, different perceptions of medical tourism in South Korea among patients from the United States, Russia, Japan and China are explored. [12] Meanwhile, WU, Li and Li described the perception of Chinese tourists of medical tourism in Taiwan. [13]

\section{PERCEPTION OF PSYCHOLOGICAL WELLBEING}

Psychological wellbeing is defined as an individual's selfevaluation of feelings of happiness and life satisfaction. [14] Psychological wellbeing is associated with emotional states and mental health, such as happiness, delight, satisfaction, depression, worry and anxiety. The determinants of wellbeing are categorised as competence, relatedness and health, wealth, personal values and freedom of choice. [15] The perception of wellbeing is interchangeable with the concept of quality of life, welfare and happiness. [16] Currently, world populations are older and live longer and have increased opportunities to enhance their quality of life and wellbeing by travelling and participating in recreational activities.

\section{BEHAVIOURAL INTENTION}

Blackwell, Miniard and Engel described intention as 'subjective judgments about how we will behave in the future. [17 p.285] Fishbein and Ajzen [18] explained behavioural intention as functions of 1) evaluative beliefs towards tourism products, 2) social factors that tend to 
provide a set of normative beliefs to tourists and 3) situational factors that can be anticipated at the time of vacation plans or commitment. Zeithaml, Berry and Parasuraman [19] classified customers' future intentions into four categories, namely, 1) referrals, 2) price sensitivity, 3) repurchase behaviour and 4) complaining behaviour. The stronger the intention to engage in a behaviour, the more likely the performance of that behaviour. Behavioural intention is used commonly as a predictor of customer loyalty and firm success. [9] The effect of the perceived value of medical services influences the behavioural intention of tourists. [13]

\section{METHODS}

\section{RESEARCH DESIGN AND SAMPLING APPROACH}

This was an exploratory study. The target population of this study was local senior tourists living in Hong Kong with experience in seeking medical treatments abroad. A convenience sampling approach was used, and senior members from ageing centres and associations as well as local senior residents were chosen.

\section{INSTRUMENT DEVELOPMENT}

The questionnaire used in this study consisted of three sections. Section I asked the respondents to indicate their perception of overseas medical service attributes. Section II was designed to compare the respondents' perception of medical service quality, wellbeing and behavioural intention towards home and host medical destinations. Seven-point Likert-type scales with end-anchors labelled 'strongly disagree' and 'strongly agree' were used in Sections I and II. Related literature on the perceived service quality of medical attributes and future behavioural intention was adopted. [5, 20, 21] Three items for the wellbeing perception measure were adopted from Hwang and Hyun. [22] Section III consisted of close-ended questions. The respondents were asked to provide their demographic profiles such as gender, age, and education level. The questionnaire was in English and in Chinese and back-to-back translation was moderated to test the validity of the items.

\section{DATA COLLECTION PROCEDURE AND DATA ANALYSIS}

Data collection was conducted in ageing centres and local residential areas in Hong Kong. The administrative staff of ageing centres and associations asked the seniors to participate in this study voluntarily. Meanwhile, research assistants approached local senior residents to participate in answering the questionnaire. Data were collected from July to October 2019, and 74 respondents returned the questionnaire.

The descriptive statistics of frequencies and percentages were employed to describe the profile of the respondents, their medical treatment behaviours and perception of overseas medical experiences. T-test analysis was used to test the mean differences of the senior tourists' perception of perceived quality, wellbeing and behavioural intention towards home and host medical services. [23]

\section{RESULTS}

\section{CHARACTERISTICS OF SENIOR RESPONDENTS}

Table 1 shows the demographic characteristics of the respondents. A total of $63.9 \%$ of the respondents are female, and $36.1 \%$ are male. Most of the respondents are over 50 years $(97.3 \%)$, and only $2.7 \%$ are between the ages of 40 and 49 years. In terms of income, $29.7 \%$ of the respondents earn less than HK\$10,000 per month, and $33.8 \%$ receive $H K \$ 10,001-30,000$ monthly. $39.2 \%$ of the respondents have completed high school education or lower, $20 \%$ have associate or higher degrees, $27 \%$ have a bachelor's degree and $13.5 \%$ have a postgraduate degree. Many of the respondents are self-employed (18.1\%) and retired (36.1\%). 
TABLE 1: DEMOGRAPHIC CHARACTERISTICS AND MEDICAL TOURISM EXPERIENCES OF RESPONDENTS

\begin{tabular}{|c|c|c|}
\hline ATTRIBUTES & $\mathbf{N}$ & $\%$ \\
\hline \multicolumn{3}{|l|}{ Gender } \\
\hline Male & 13 & 36.1 \\
\hline Female & 23 & 63.9 \\
\hline \multicolumn{3}{|l|}{ Age } \\
\hline 40-49 years old & 2 & 2.7 \\
\hline $50-55$ years old & 29 & 39.2 \\
\hline $56-60$ years old & 21 & 28.4 \\
\hline $61-65$ years old & 17 & 23.0 \\
\hline Above 65 years old & 5 & 6.7 \\
\hline \multicolumn{3}{|l|}{ Income (monthly HK\$) } \\
\hline$<\mathrm{HK} \$ 10,000$ & 22 & 29.7 \\
\hline$H K \$ 10,001-30,000$ & 25 & 33.8 \\
\hline$H K \$ 30,001-50,000$ & 23 & 31.1 \\
\hline$H K \$ 50,001-80,000$ & 4 & 5.4 \\
\hline \multicolumn{3}{|l|}{ Education } \\
\hline High school or below & 29 & 39.2 \\
\hline $\mathrm{AD} / \mathrm{HD}$ & 15 & 20.3 \\
\hline Bachelor degree & 20 & 27.0 \\
\hline Postgraduate degree & 6 & 8.1 \\
\hline Professional certificate & 5 & 5.4 \\
\hline \multicolumn{3}{|l|}{ Occupation } \\
\hline Government official & 5 & 6.9 \\
\hline Teacher/professor & 3 & 4.2 \\
\hline Executive/manager & 6 & 8.3 \\
\hline Administrative staff & 9 & 12.5 \\
\hline Professional/technician & 10 & 13.9 \\
\hline Self-employed & 13 & 18.1 \\
\hline Retiree/Not working & 26 & 36.1 \\
\hline
\end{tabular}




\section{PERCEIVED MEDICAL SERVICE QUALITY BY MEDICAL TOURISM DESTINATION}

Perceived medical service quality by medical tourism destination is presented in Table 2. Among the seven

edical tourism destinations, the respondents perceive the United States as having the most positive medical service qualities (mean $=4.56)$, followed by Japan (mean $=4.32$ ) and Taiwan (mean $=4.17$ ). Meanwhile, the respondents perceive China and South Korea as having the least positive medical service qualities, with a mean of 4.05 and 3.66, respectively. The top three medical attributes are 'the physicians adequately explained my condition, examination results and the medical process' (mean = 4.53), 'the physicians paid adequate attention to my concerns in deciding on a medical procedure' (mean = 4.46) and 'the physicians allowed me to ask many questions' (mean $=4.43$ ). Meanwhile, the respondents rate the following as the least positive medical attributes: 'the process for setting up the medical procedure appointment was simple and easy' (mean $=3.77$ ) and 'assistance with financial arrangement, including advance estimates for fees and payments' (mean = 3.74).

\section{DIFFERENT PERCEPTIONS OF MEDICAL SERVICE ATTRIBUTES BY MEDICAL TOURISM DESTINATION}

Table 3 describes the mean differences between medical service attributes, wellbeing, and behavioural intention by medical tourism destination (Hong Kong and overseas destination).

For perceived medical quality attributes, 8 out of 20 items differ significantly. The respondents perceive more positive experiences in overseas medical destinations compared with Hong Kong. These items include 'medical staff was polite and friendly' (meanHong Kong $=3.57$. meanoverseas $=4.23, \mathrm{t}$-value $=-3.95, \mathrm{p}<.01$ ), 'the physicians adequately explained my condition, examination results and the medical process' (meanHong Kong $=4.00$, meanoverseas $=4.52, \mathrm{t}$-value $=-3.37, p<.01 \mathrm{f}$ and 'the physicians paid adequate attention to my concerns in deciding on a medical procedure' (meanHong Kong $=3.81$, meanoverseas $=4.35, \mathrm{t}$-value $=$ $3.30, p<.011)$. By contrast, the respondents perceive only two items in terms of medical quality attributes that are more positive in Hong Kong compared with overseas medical destinations. These items are 'the process for the medical procedure appointment was simple and easy' (meanHong Kong $=4.10$, meanoverseas $=3.81, \mathrm{t}$-value $=$ $2.18, p<.05)$ and 'ease of assembly and transmission of medical record/information' (meanHong Kong $=4.13$, meanoverseas $=3.87, \mathrm{t}$-value $=2.10, \mathrm{p}<.05)$.

In terms of wellbeing perception, two out of four items have mean differences between Hong Kong and overseas medical destinations. The respondents perceive wellbeing more positively in Hong Kong compared with overseas medical tourism destinations. These items are 'the medical treatment met my overall wellbeing needs' (meanHong Kong $=4.00$, meanoverseas $=4.32$, t-value $=-2.55, p<.05$ ) and 'the medical treatment played a very important role in my social wellbeing' (meanHong Kong $=4.03$, meanoverseas $=4.32, \mathrm{t}$-value $=-2.51, \mathrm{p}<.05)$. However, no mean difference is observed in behavioural intention towards medical tourism destinations. 


\begin{tabular}{|c|c|c|c|c|c|c|c|c|}
\hline MEDICAL TOURISM ATTRIBUTES & $\begin{array}{l}\text { TAIWAN } \\
(\mathrm{N}=7)\end{array}$ & $\begin{array}{l}\text { SOUTH } \\
\text { KOREA } \\
(\mathrm{N}=6)\end{array}$ & $\begin{array}{l}\text { JAPAN } \\
(\mathrm{N}=4)\end{array}$ & $\begin{array}{l}\text { CHINA } \\
(\mathrm{N}=4)\end{array}$ & $\begin{array}{l}\text { USA } \\
(\mathrm{N}=4)\end{array}$ & $\begin{array}{l}\text { MALAYSIA } \\
(\mathrm{N}=2)\end{array}$ & $\begin{array}{l}\text { THAILAND } \\
(\mathrm{N}=2)\end{array}$ & $\begin{array}{l}\text { MEAN } \\
\text { AVERAGE }\end{array}$ \\
\hline $\begin{array}{l}\text { 1. The process for the medical } \\
\text { procedure appointment } \\
\text { was simple and easy }\end{array}$ & 3.86 & 3.50 & 4.00 & 4.00 & 4.00 & 3.00 & 4.00 & 3.77 \\
\hline $\begin{array}{l}\text { 2. Ease of assembled and } \\
\text { transmitted of medical } \\
\text { record/information }\end{array}$ & 4.00 & 3.33 & 4.00 & 4.00 & 4.25 & 3.50 & 4.00 & 3.87 \\
\hline $\begin{array}{l}\text { 3. It is short waiting time for } \\
\text { the medical examination }\end{array}$ & 3.71 & 3.50 & 4.00 & 4.50 & 4.00 & 4.00 & 5.00 & 4.10 \\
\hline $\begin{array}{l}\text { 4. The physicians paid } \\
\text { enough attention to my } \\
\text { concerns }\end{array}$ & 4.29 & 3.67 & 5.00 & 4.00 & 4.75 & 4.50 & 5.00 & 4.46 \\
\hline $\begin{array}{l}\text { 5. The physicians adequately } \\
\text { explained my condition, } \\
\text { examination results, and } \\
\text { medical process }\end{array}$ & 4.86 & 3.83 & 5.00 & 4.25 & 4.75 & 4.50 & 4.50 & 4.53 \\
\hline $\begin{array}{l}\text { 6. The physicians allowed me } \\
\text { to ask many questions }\end{array}$ & 4.71 & 3.83 & 4.50 & 4.50 & 5.00 & 4.00 & 4.50 & 4.43 \\
\hline $\begin{array}{l}\text { 7. The medical staff has good } \\
\text { communication skills }\end{array}$ & 4.57 & 3.33 & 4.50 & 4.25 & 5.00 & 4.00 & 4.50 & 4.31 \\
\hline $\begin{array}{l}\text { 8. Medical staff was polite } \\
\text { and friendly }\end{array}$ & 4.50 & 3.67 & 4.50 & 4.00 & 4.50 & 4.00 & 4.50 & 4.24 \\
\hline $\begin{array}{l}\text { 9. The hospital has state-of- } \\
\text { the-art facilities and } \\
\text { equipment }\end{array}$ & 4.00 & 3.83 & 4.50 & 3.50 & 4.75 & 4.00 & 4.00 & 4.08 \\
\hline $\begin{array}{l}\text { 10. Hospital care facilities were } \\
\text { easy to find }\end{array}$ & 4.14 & 3.83 & 5.00 & 3.50 & 4.50 & 4.00 & 3.50 & 4.07 \\
\hline $\begin{array}{l}\text { 11. The hospital amenities were } \\
\text { conveniently located }\end{array}$ & 4.14 & 4.00 & 3.75 & 3.75 & 4.00 & 4.00 & 3.50 & 3.88 \\
\hline $\begin{array}{l}\text { 12. The hospital has a strong } \\
\text { concern of patient safety }\end{array}$ & 4.29 & 4.00 & 4.50 & 4.00 & 4.50 & 4.50 & 3.50 & 4.18 \\
\hline $\begin{array}{l}\text { 13. The hospital's attention to } \\
\text { patient's privacy and } \\
\text { disclosure }\end{array}$ & 4.43 & 4.00 & 4.50 & 4.00 & 4.75 & 4.50 & 4.00 & 4.31 \\
\hline $\begin{array}{l}\text { 14. The hospital has } \\
\text { acceptable protection } \\
\text { against medical } \\
\text { malpractice and liability }\end{array}$ & 4.29 & 3.83 & 4.50 & 4.25 & 4.50 & 4.50 & 4.00 & 4.27 \\
\hline $\begin{array}{l}\text { 15. The payment procedure } \\
\text { was quick and simple }\end{array}$ & 4.14 & 3.67 & 3.75 & 4.25 & 4.50 & 4.50 & 4.50 & 4.19 \\
\hline $\begin{array}{l}\text { 16. Convenient package } \\
\text { pricing }\end{array}$ & 3.86 & 3.67 & 4.0 & 4.25 & 4.25 & 5.00 & 4.50 & 4.22 \\
\hline $\begin{array}{l}\text { 17. Assistance with financial } \\
\text { arrangement }\end{array}$ & 3.86 & 3.33 & 4.25 & 4.0 & 3.25 & 4.00 & 3.50 & 3.74 \\
\hline $\begin{array}{l}\text { 18. Convenient hospital } \\
\text { transportation } \\
\text { arrangement }\end{array}$ & 4.00 & 3.67 & 4.00 & 4.25 & 4.25 & 3.50 & 4.00 & 3.95 \\
\hline $\begin{array}{l}\text { 19. Good coordination of } \\
\text { arrangements among the } \\
\text { patient, hospital, and } \\
\text { other businesses }\end{array}$ & 3.71 & 3.33 & 4.25 & 3.75 & 4.25 & 4.00 & 4.00 & 3.90 \\
\hline $\begin{array}{l}\text { 20. I am very satisfied with } \\
\text { services received }\end{array}$ & 4.14 & 3.50 & 4.00 & 4.00 & 4.50 & 4.50 & 4.00 & 4.09 \\
\hline Mean average & 4.17 & 3.66 & 4.32 & 4.05 & 4.41 & 4.12 & 4.15 & 4.13 \\
\hline
\end{tabular}




\begin{tabular}{|c|c|c|c|c|}
\hline \multirow[b]{2}{*}{ Construct } & \multicolumn{2}{|c|}{ Mean (SD) } & \multirow{2}{*}{ t-value } & \multirow{2}{*}{ Sig. } \\
\hline & Hong Kong & Overseas & & \\
\hline \multicolumn{5}{|l|}{ Perceived medical quality } \\
\hline $\begin{array}{l}\text { 1. The process for the medical procedure } \\
\text { appointment was simple and easy }\end{array}$ & $4.10(.70)$ & $3.81(.54)$ & 2.18 & $.03^{*}$ \\
\hline $\begin{array}{l}\text { 2. Ease of assembled and transmitted of medical } \\
\text { record/information }\end{array}$ & $4.13(.71)$ & $3.87(.56)$ & 2.10 & $.04^{*}$ \\
\hline 3. It is short waiting time for the medical examination & $3.35(1.01)$ & $3.94(.81)$ & -2.37 & $.02 *$ \\
\hline $\begin{array}{l}\text { 4. The physicians paid enough attention to my } \\
\text { concerns }\end{array}$ & $3.81(.94)$ & $4.35(.79)$ & -3.30 & $.00^{* *}$ \\
\hline $\begin{array}{l}\text { 5. The physicians adequately explained my condition, } \\
\text { examination results, and medical process }\end{array}$ & $4.00(.77)$ & $4.52(.67)$ & -3.37 & $.00^{* *}$ \\
\hline 6. The physicians allowed me to ask many questions & $3.87(.76)$ & $4.45(.72)$ & -3.15 & $.00^{* *}$ \\
\hline 7. The medical staff has good communication skills & $4.10(.70)$ & $4.29(.69)$ & -1.29 & .20 \\
\hline 8. Medical staff was polite and friendly & $3.57(.81)$ & $4.23(.72)$ & -3.95 & $.00^{* *}$ \\
\hline $\begin{array}{l}\text { 9. The hospital has state-of-the-art facilities and } \\
\text { equipment }\end{array}$ & $3.71(.73)$ & $4.10(.70)$ & -2.44 & $.02 *$ \\
\hline 10. Hospital care facilities were easy to find & $3.94(.44)$ & $4.06(.72)$ & -.94 & .35 \\
\hline 11. The hospital amenities were conveniently located & $3.77(.61)$ & $3.87(.76)$ & -.72 & .47 \\
\hline 12. The hospital has a strong concern of patient safety & $4.16(.77)$ & $4.16(.68)$ & .00 & 1.00 \\
\hline $\begin{array}{l}\text { 13. The hospital's attention to patient's privacy and } \\
\text { disclosure }\end{array}$ & $4.23(.84)$ & $4.26(.72)$ & -.20 & .83 \\
\hline $\begin{array}{l}\text { 14. The hospital has acceptable protection against } \\
\text { medical malpractice and liability }\end{array}$ & $4.13(.71)$ & $4.23(.84)$ & -.61 & .54 \\
\hline 15. The payment procedure was quick and simple & $4.16(.82)$ & $4.10(.59)$ & .38 & .70 \\
\hline 16. Convenient package pricing & $3.87(.88)$ & $4.06(.62)$ & -1.18 & .24 \\
\hline 17. Assistance with financial arrangement & $3.77(.76)$ & $3.71(.78)$ & .31 & .75 \\
\hline 18. Convenient hospital transportation arrangement & $3.97(.83)$ & $3.97(.70)$ & .00 & 1.00 \\
\hline $\begin{array}{l}\text { 19. Good coordination of arrangements among the } \\
\text { patient, hospital, and other businesses }\end{array}$ & $3.90(.70)$ & $3.84(.68)$ & .49 & .62 \\
\hline 20. I am very satisfied with services received & $3.90(.79)$ & $4.06(.62)$ & -1.15 & .25 \\
\hline \multicolumn{5}{|l|}{ Wellbeing perception } \\
\hline $\begin{array}{l}\text { 1. The medical treatment met my overall well-being } \\
\text { needs }\end{array}$ & $4.00(.57)$ & $4.32(.65)$ & -2.55 & $.01^{*}$ \\
\hline $\begin{array}{l}\text { 2. The medical treatment played a very important role } \\
\text { in my social well-being }\end{array}$ & $4.03(.70)$ & $4.32(.65)$ & -2.51 & $.01^{*}$ \\
\hline $\begin{array}{l}\text { 3. The medical treatment played a very important role } \\
\text { in enhancing my quality of life }\end{array}$ & $4.26(.63)$ & $4.48(.62)$ & -1.65 & .10 \\
\hline \multicolumn{5}{|l|}{ Behavioral intention } \\
\hline 1. Say positive things to my relatives and close friends & $4.06(.77)$ & $4.26(.72)$ & -1.18 & .24 \\
\hline 2. Recommend to my relatives and close friends & $4.13(.76)$ & $4.26(.68)$ & -.89 & .38 \\
\hline $\begin{array}{l}\text { 3. Continue to use this hospital/clinic service in the } \\
\text { future }\end{array}$ & $4.16(.73)$ & $4.03(.70)$ & .84 & .40 \\
\hline $\begin{array}{l}\text { 4. Spend more money on the medical treatment even } \\
\text { if the price increased }\end{array}$ & $3.68(.94)$ & $4.03(.65)$ & -1.94 & .06 \\
\hline
\end{tabular}

${ }^{*} P<.05,{ }^{* *} P<.01$ 
This research assesses tourists' perception of medical quality attributes by medical tourism destination and compares tourists' different perceptions of medical service attributes, wellbeing, and behavioural intention by medical tourism destination. The results support the previous study of Wu et al. [13]

The results show that tourists rate medical tourism attributes differently. Most of the Hong Kong seniors consider visiting medical tourism destinations near the region, such as China, Japan, Malaysia, South Korea, Taiwan and Thailand. Only the United States is mentioned by the senior tourists for medical visits in a different continent. The tourists have a more positive perception of the medical treatments they received in the United States, Japan and Taiwan. Medical tourism attributes that are perceived positively include high-quality physicians and staff, specifically, their excellent communication skills and ability to answer questions responsively and explain medical procedures well, which is like the study of An. [12] Meanwhile, physicians in Japan focus on medical procedures and processes. Furthermore, the respondent's rate medical services received in China and South Korea as the lowest. The tourists have a low perception of hospital facilities and locations in China. Tourists who have received medical treatment in South Korea rate the communication skills of the staff, ease of obtaining medical information and waiting time for medical examinations as low.

This investigation on perceived medical quality and wellbeing indicates that such perceptions differ depending on the medical tourism destination. Senior tourists who have received medical treatment in overseas medical tourism destinations have a positive perception of the quality of physicians and staff in terms of being polite and friendly to patients, providing adequate information on medical procedures and paying attention to the patient's needs. Satisfactory hospital facilities and short waiting time are rated more positively in overseas destinations compared with Hong Kong. In addition, overseas physicians and staff are willing to answer questions, provide details on medical procedures and processes and are polite and friendly. This perception may be due to the hospital or clinic situations in Hong Kong, which are often extremely busy and packed. Thus, the medical staff may not have extra time for the patients. Hong Kong medical services are well perceived in terms of ease of medical procedure appointments and ease of assembly and transmission of medical records.

Managerial implications are provided. Firstly, medical tourism destinations can offer certain medical treatments and services that can meet seniors' preferences in terms of time and finances, such as medical check-ups and dental surgery. This implication can enhance travel itineraries embedded with medical treatment purposes. Secondly, Taiwan and South Korea are major medical tourism destinations for Hong Kong senior tourists. However, the United States and Japan are highly rated in terms of overall satisfaction in medical services. These countries can improve the level of medical and service standards to sustain medical tourism awareness. Lastly, high-quality physicians and staff are the key strengths of overseas medical tourism destinations. Hospitals, clinics and medical tourism management should emphasise quality training for medical staff and related employees to enhance the quality of medical care. [13] The promotion of this service niche can strengthen the positioning of hospitals and clinics in medical tourism destinations. For instance, South Korea is recommended to position itself as a medical tourism destination in terms of high-tech-related sophisticated treatment; fostering excitement, sense of belongingness and self-respect; and being well-respected. [9, 23]

\section{LIMITATIONS AND FUTURE RESEARCH}

This study is not without limitations. The sample size of seniors with medical tourism experiences abroad is relatively small. Increasing the number of respondents can reflect comprehensive insights. The data were collected during the political instability in Hong Kong. Therefore, the perception of local medical treatments and services may differ. Future research can be conducted at a different time to enhance the generalizability of the perception of the respondents.

\section{References}

1. Cornell J. Medical tourism: The newest of niches. Tourism Recreation Research 2006; 31 (1): 99-102.

2. Pan TJ, Chen WC. Chinese medical tourists - Their perceptions of Taiwan. Tourism Management 2004; 44: 108-112. 
3. Ebrahim AH, Ganguli S. A comparative analysis of medical tourism competitiveness of India, Thailand and Singapore. Tourism 2019; 67(2): 102-115.

4. Manaf NHA, Hussin H, Kassim PNJ, Alavi R, Dahari Z. Medical tourism service quality: Finally some empirical findings. Total Quality Management 2015; 26(9): 10171028.

5. Huang VCS, Kucukusta D, Song H. Medical tourism development in Hong Kong: An assessment of the barriers. Tourism Management 201 1; 32(5): 995-1005.

6. Ye BH, Qiu HZ, Yuen PP. Motivations and experiences of Mainland Chinese medical tourists in Hong Kong. Tourism Management 2011; 32(5): 1125-1127.

7. Zsarnoczky M, David L, Mukayev Z, Baiburiev R. Silver tourism in the European union. GeoJournal of Tourism and Geosites 2016; 2(18): 224-232.

8. Shoemaker S. Segmentation of the senior pleasure travel market. Journal of Travel Research 1989; $27(3)$ : 14-21.

9. Guiry M, Vequist DGIV. South Korea's medical tourism destination brand personality and the influence of personal values. Asia Pacific Journal of Tourism Research 2015; 20(5), 563-584.

10. Prajitmutita LM, Perenyi A, Prentice C. Quality, value? Insights into medical tourists' attitudes and behaviors. Journal of Retailing and Consumer Services 2016; 31: 207-216.

11. Chuang TC, Liu JS, LU LYY, Lee Y. The main paths of medical tourism: From transplantation to beautification. Tourism Management 2014; 45: 49-58.

12. An D. Understanding medical tourist in Korea: Crosscultural perceptions of medical tourism among patients from the USA, Russia, Japan, and China. Asia Pacific Journal of Tourism Research 2014; 19(10): 1141 1169.

13. Wu HC, Li T, Li MY. A study of behavioral intentions, patient satisfaction, perceived value, patient trust and experiential quality for medical tourists. Journal of Quality Assurance in Hospitlauty \& Tourism 2016; 17(2): 114-150.

14. Okun M, Stock W. Correlates and components of subjective well-being. Journal of Applied Gerontology 1984; 6(1): 95-112.

15. Abraham J, Velenczei A, Szabo A. Perceived determinants of well-being and enjoyment level of leisure activities. Leisure Sciences 2012; 34: 199-216.
16. Puczko L, Smith M. Tourism-specific quality-of-life index: the Budapest model Quality-of-life community indicators for parks, recreation and tourism management. Springer; 2011.

17. Blackwell RD, Miniard PW, Engel JF. Consumer behaviour. Texas: Harcourt College Publisher; 2001.

18. Fishbein M, Ajzen I. Belief, attitude, intention, and behaviour: An introduction to theory and research. MA: Addison-Wesley; 1975.

19. Zeithaml VA, Berry LL, Parasuraman A. The behavioural consequences of service quality. Journal of Marketing 1996; 60(2): 31-46.

20. Choi KS, Cho WH, Lee S, Lee H, Kim C. The relationships among quality, value, satisfaction and behavioral intention in health care provider choice: A South Korea study. Journal of Business Research 2004; 57(8): 913-921.

21. Mechinda P, Serirat S, Anuwichanont J, Gulid, N. An examination of tourists' loyalty towards medical tourism in Pattaya, Thailand. International Business \& Economics Research Journal 2010; 9(1): 55-70.

22. Hwang J, Hyun SS. First-class airline travelers' perception of luxury goods and its effect on loyalty formation. Current Issues in Tourism 2017; 20(5): 497520.

23. Hair JFJr, Black WC, Babin BJ, Anderson RE, Tatham RL. Multivariate data analysis: Sixth edition. New Jersey: Pearson Prentice Hall; 2006. 